\title{
Research on the Influence of Accounting Environmental Change on Financial Accounting Theoretical Innovation
}

\author{
Nan Zhang \\ Beijing Forestry University, 100083
}

\begin{abstract}
With the development of modern economy and society, in order to produce a more positive impact on enterprise development and operation process, it is necessary for the financial and accounting work to analyze comprehensively the emergence of new changes in accounting environment, this environmental change has a certain role on financial accounting theory innovation. In the new era of the financial environment, the actual impact of environmental change reflects in accounting, human capital accounting, computer information technology, networking, work and other aspects of diversification. From the perspective of environmental change, this paper analyzes the actual influence generated by theoretical innovation of the accounting work. Only accounting objectives, asset concepts, accounting elements and accounting assumptions achieve changes, can accounting work be able to provide more accurate and comprehensive information for enterprise development to make direction for enterprise management to make measures for the development.
\end{abstract}

Keywords- Accounting Environment, Financial Accounting Theory, Change, Influence

\section{INTRODUCTION}

Accounting theory structure has a relatively important part which is accounting environment, this environment has a certain impact on today's financial accounting methods and the theory. Smooth development of financial and accounting work inseparable from all aspects of the society and economic information to a certain extent, that's to say, the whole process of accounting development should be analyzed from the fundamental with great times, it is a commercial development product to meet the various needs of the pace of development of the current economy ${ }^{[1]}$. The further deepening of China's economic reform and opening up levels further rising makes that China's economic development has formed a unique socialist market economy. After the accession to the WTO, the entire accounting environment began to change, which is bound to make financial accounting theory have comprehensive, wideranging and multi-level impact.

\section{ANALYSIS OF RELATED FACTORS IMPACTING THE ACCOUNTING ENVIRONMENTAL CHANGE}

\section{A. Political Environment}

Under the joint action of our political system adopted at this stage as well as other relevant factors, the government's current focus on resource allocation and resource requirements have a big difference, financial accounting model is not the same in different periods, and the political system will cause that the entire financial accounting model generates a bigger gap. Ever since our country joined WTO, the whole economy has been able to largely adapt to modern international practice in the development process, and makes economic development focus and the actual direction of the government adapt to changes in the way of political reform. With the implementation of various policies, the rise of democracy degree, accounting staff have more favorable basic environment, these inherent advantages makes financial and accounting work at this stage of the development more standardized, and the prospects brighter.

\section{B. Legal Environment}

With the rising awareness of democracy and law, the judiciary, together with the relevant government departments have to discuss and develop a variety of accounting standards, accounting, insurance law and other relevant laws, combined with the characteristics of the times, and update the relevant laws ${ }^{[2]}$. Although there are still some problems in our legal system to some extent, it still need to be continuously improved and strengthened. However, compared with before, the work in the field of legal environment of financial accounting really has made great progress. Different legal environment, will inevitably lead to the entire accounting system changes, promoting China's accounting environment towards a more harmonious and healthy direction.

\section{Economic Environment}

Accounting environment has economic environment, essentially for analysis, it is a decisive factor in the development of accounting standards and accounting theory formation, but also the basic factors to carry out various accounting practices work. Economic factors in the accounting environment components include economic system, economic structure, and the degree of economic stability and the level of economic development, economic policy and other factors outside world formulated by the government ${ }^{[3]}$. Since our country joined WTO and the implementation of reform and opening up, the whole economy has made rapid development on the basis and also faced increasing competitive pressure, in developing competitive strategies accordingly, companies should also take full consideration of various factors at home and abroad, the entire accounting environment is bound to produce a variety of new changes. 


\section{ANALYSIS OF THE INFLUENCE OF ACCOUNTING ENVIRONMENTAL CHANGE ON FINANCIAL ACCOUNTING THEORETICAL INNOVATION}

\section{A. Change of Asset Ideas}

Under the influence of changes in accounting environment factors, the concept of financial accounting theory assets also had a corresponding change. Financial accounting assets concept in the past are generally only all kinds of hard assets in enterprises which does not include a variety of soft assets. To analyze this concept from the perspective of a comprehensive notion, it belongs to concept of a larger defective and more one-sided. Under the influence, corporate assets and liabilities in the actual calculations cannot reflect the greater value, under the continuous impact of business capital and enterprise resource, definitions of various assets inevitably will go toward a broad direction ${ }^{[6]}$. Therefore, the assets and economic resources of new era have a large similarity, in addition to a variety of hard assets, there is also a certain soft assets, in which the former includes various physical assets based on capital and financial resources, such as corporate cash, bank deposits, fixed assets, and short-term investments or long-term investment, and also includes a variety of soft assets based on soft resources and financial capital, such as customer assets, relationship assets, organizational assets, human assets, ecological assets and so on.

\section{B. Changes in Accounting Purposes}

In the process of economic development of the past, the industry accounted for a large proportion, in such circumstances, financial accounting purposes were generally divided into the decision-making useful concept and the concept of fiduciary duty. These two goals both produced a certain positive impact on the point of the whole enterprise resource allocation and utilization, therefore, the financial accounting goal of corporate carried out under the background of the industrial era is to maximize profits and performance appraisal. In the knowledge economy at the present stage, in order to achieve sustainable development, the enterprise must change this economic nature, further highlight the economic value of fairness and impartiality. Therefore, the corporate financial accounting objectives should produce a corresponding change to change the performance-oriented objectives in the past and adhere to equity-oriented development ${ }^{[4]}$. This companies accounting target will reflect the business conditions and financial situation more accurately, and the bear is a function of the data or information. It is also important information to protect or achieve other groups or stakeholder interests, and put more emphasis on social equity or production relations.

\section{Changes in Accounting Objects}

Financial accounting object is an important factor in a modern enterprise financial accounting theory, it has played a decisive role to some extent in the content of financial accounting. Past financial accounting object exists a large deviation, the entire accounting only emphasizes the specific economic and business accounting in enterprises which seriously hope to understand the flow process and business performance status through representation of various economic activities generated by the enterprise funds, difficult to attach importance to the situation that exists between corporate performance and cash flow process. In this stage of enterprise development environment, at the same time of financial accounting work in relation to the importance of property rights, we must also focus on the entire accounting work on corporate property relations. Therefore, the start and end of the business operation is the actual property transaction contract formation and release action $^{[7]}$. The operation nature of the modern enterprise is to fulfill the process of property rights, the main purpose is to be able to run the full realization of property value, which reflects the movement during operation of corporate property, to control it can scientifically accurately reflect the relationship between corporate responsibility and equity in the actual course of the campaign, to achieve the full realization of the rights and interests of enterprises from the fundamental objectives.

\section{Changes in Accounting Elements}

According to corporate accounting guidelines related to the implementation of the present analysis, corporate accounting work includes assets, liabilities, equity, revenues, expenses, profits and other six different elements. In the traditional period of industrial rapid development, the six elements of accounting work can basically meet the basic requirements, but in the new era of knowledge economy, the corporate accounting basic content also had a corresponding change. The human resource assets and knowledge assets gradually occupy an important position in the structure of corporate assets, and the related proportion is also rising. Over the past, the six elements of the financial assets share of total assets in the modern enterprise is beginning to show a downward trend. If the corporate financial accounting principles and elements are not changed, the result is bound to be one-sided accounting errors or phenomenon [5] Therefore, on the basis of six elements adopted in the past, the modern corporate finance work should also use the method of accounting knowledge assets and human assets to highlight the major role in human resource accounting work in order to establish and improve the modern corporate financial accounting job to run the system.

\section{E. Changes in Accounting Assumptions}

Accounting assumption in accounting theory of modern enterprise is a based content, in order to successfully complete accounting work, it is necessary to carry out innovative accounting assumptions. As a prerequisite accounting work, the change of enterprise development environment is bound to change this assumption work resulting in a corresponding impact. At the time of the accounting reform, in conjunction with the actual development of the status, take the change period as the phase or solid phase and dynamically reflect various accounting information, accurately and thoroughly master the relevant accounting information, thus helping to serve a variety of economic decisions. In the actual process of 
competition, enterprises are bound to intensify. Therefore, it faced bankruptcy at any time, merger or liquidation problem, working to innovate on accounting assumptions can reduce this risk occurring after economic losses.

When conducting monetary measurement assumptions, using single currency methods for measuring is difficult to meet the relevant requirements of the user, and therefore should be able to give more information which will have a positive effect on assets, elements, measurement, and other non-monetary in the future. Faced with performance appraisal using monetary measures, we can use corporate financial accounting work of non-monetary.

\section{F. Summary Financial Report and Achieve Innovation}

There was lag sexual of phenomenon of enterprise financial accounting reports in the past, under the influence of change of accounting environment, financial accounting reports should also combine with trend of the of enterprise development, accurately reflect the development of actual status. Ensure that enterprises leader understand and master the development of actual status within shorter period of time, which will be able to provide larger support for the leadership and manage to develop the various timeliness sexual of policy fundamentally, and lay a good foundation and theory for enterprises to achieve long-term development ${ }^{[8]}$. Under the new era, the accounting theory also makes use of human resources and knowledge system in the process of the development of enterprises, which makes the innovative performance more prominent, thus improving the old corporate financial accounting theory for a variety of nonmonetary factors of not comprehensive understanding. Today's enterprise financial accounting work must continue to develop and introduce excellent staff and management knowledge to ensure variety of financial accounting innovation theory, and provide data and information support for the business leaders to develop strategies fundamentally.

\section{CONCLUSION}

With the continuous development of modern enterprises, only combined with the development factors of the times and competitive factors in the market, can financial accounting work achieve constant change and ensure the smooth progress of corporate financial accounting work. Under the influence of this environmental change, the theoretical changes are mainly reflected in asset concept, accounting purpose, accounting object, accounting elements, accounting assumptions and summary methods. As a systems engineering, only innovative of corporate finance work removes antiquated concepts and theories work and continues to expand the current accounting theory, can it be able to provide a theoretical and information support for enterprise development.

\section{REFERENCES}

[1] Huang X, Zhang J. Accounting Environmental Change and Financial Accounting Theoretical Innovation [J]. Audit and Economic Research, 2011 (3).

[2] Zhang Y. Discussion on Accounting Environmental Change and Financial Accounting Theoretical Innovation [J]. Modern Economic Information, 2011(20).

[3] Wang B. Discussion on Accounting Environmental Change and Financial Accounting Theoretical Innovation [J]. Assets and Finances in Administration and Institution, 2014 (8).

[4] Sun J. Analysis on Accounting Environmental Change and Financial Accounting Theoretical Innovation at This Stage [J]. Market Modernization, 2011 (33).

[5] Liu C, Wang F. Robust Hळ Control for Satellite Attitude Control System with Uncertainties and Additive Perturbation [J]. International Journal of Science, 2014, 1(2): 1-9.

[6] Feng H. Interactive Study of Financial Reporting Reform and Reconstruction of Financial Analysis System [D]. Ocean University of China, 2012.

[7] Shao L. Discussion on Accounting Environmental Change and Financial Accounting Theoretical Innovation [J]. Operators, 2013 (13).

[8] Xu L, Jia Y. Development of Financial Accounting Theory and Method [J]. China Township Enterprises Accounting, 2003 (10). 